\title{
ANALISIS HUBUNGAN DUKUNGAN PENGAWAS MINUM OBAT TB-PARU DENGAN KESEMBUHAN MELALUI STUDI EPIDEMIOLOGI BERSIFAT ANALITIK
}

\author{
Maharso, Zulfikar, Imam Santoso \\ Poltekkes Kemenkes Banjarmasin Jurusan kesehatan Lingkungan Banjarbaru \\ Email : maharsom@gmail.com
}

\begin{abstract}
Analysis Of Relationship Between Supporting The Observer Of Pulmonary Tb Treatment With Cured By Analitycal Epidemiological Studies. Pulmonary Tuberculosis is a communicable disease which are virulent and lethal. One of ten latent infections (hidden) will develop into active disease, which if not treated properly will be fatal for the patient. Most of TB patients can be recovered, if they meet the applicable provisions of the treatment. Epidemiological studies about relationship between supporting the observer of pulmonary tb treatment with cured in Puskesmas Purwodadi I Kabupaten Grobogan, prove not associated statistically. While in Puskesmas Mangkang Semarang Barat, shows there is significantly association between supporting the observer of pulmonary tb treatment with cured. The problem is which one of the finding be able to be the base of decision making in management of pulmonary TB program nationally. The purpose of this study was getting explanation and base of decision making, whether the finding in 2 puskesmas which produce different finding be able to be base of general decision making (inferensial). The epidemiological study used systematic review methods. Source of research data was from the literature, obtained through the Internet, relevant research, especially research in Puskesmas Purwodadi I Kabupaten Grobogan dan di Puskesmas Mangkang Semarang Barat. The result showed that epidemiological study in both Puskesmas Purwodadi I and Puskesmas Mangkang had some similiarity that were analytical, used chi-square test, and in the method of sampling (Non Probability). While in other study method was different, both in study design, number of sample, and the respondent's age criteria. Finding of epidemiological study in both Puskesmas Purwodadi I and Puskesmas Mangkang is inferential, so that only are specific site and does not apply to other population.
\end{abstract}

Keywords : analitycal epidemiology, pulmonary-tb

\begin{abstract}
Abstrak : Analisis Hubungan Dukungan Pengawas Minum Obat TB-Paru dengan Kesembuhan melalui Studi Epidemiologi Bersifat Analitik. Tuberkulosis paru adalah penyakit menular yang ganas dan mematikan. Satu dari sepuluh infeksi laten (tersembunyi) akan berkembang menjadi penyakit aktif, yang jika tidak diobati dengan benar akan berakibat fatal bagi penderita. Sebagian besar pasien TB dapat disembuhkan, dengan syarat apabila mereka mematuhi ketentuan yang diberlakukan dalam pengobatan. Studi epidemiologi tentang hubungan Pengawas Minum Obat dengan kesembuhan Penderita TB paru di Puskesmas Purwodadi I Kabupaten Grobogan, terbukti secara statistik tidak berhubungan. Sedangkan di Puskesmas Mangkang Semarang Barat secara statistik justru menunjukkan ada hubungan yang signifikan antar dukungan Pengawas Minum Obat dengan kesembuhan pada penderita tb-paru. Masalahnya adalah menentukan temuan manakah yang dapat dijadikan dasar pengambilan keputusan dalam pengelolaan program pengobatan tb-paru secara nasional. Tujuan dari studi ini adalah mendapatkan kejelasan dan dasar pengambilan keputusan apakah temuan studi di 2 puskesmas yang menghasilkan temuan yang berbeda dapat dijadikan dasar pengambilan keputusan secara general (inferensial). Metode studi epidemiologi ini menggunakan metode systematic review. Sumber data penelitian ini berasal dari literatur yang diperoleh melalui internet, penelitian yang relevan, terutama penelitian di Puskesmas Purwodadi I Kabupaten Grobogan dan di Puskesmas Mangkang Semarang Barat. Hasil penelitian menunjukkan bahwa studi epidemiologi baik di Puskesmas Purwodadi I maupun di Puskesmas Mangkang mempunyai persamaan yaitu sama-sama bersifat analitik, sama-sama menggunakan uji statistik
\end{abstract}


Chi square, dan dalam hal cara pengambilan sampel (Non Probability). Sedangkan metode sudi lainnya berbeda, baik dalam hal rancangan studi, besarnya sampel, maupun kriteria umur responden. Temuan studi epidemiologi di Puskesmas Purwodadi I maupun di Puskesmas Mangkang bersifat inferensial, sehingga hanya bersifat spesific site dan tidak berlaku pada populasi lainnya.

Kata Kunci : epidemiologi analitik, tb-paru

\section{PENDAHULUAN}

A. Latar Belakang

Pada tahun 2000 di seluruh dunia diperkirakan muncul lebih dari 10,2 juta penderita baru tb-paru, dan Indonesia menempati peringkat 3 terbesar setelah Cina dan India untuk kasus tb-paru. Pada tahun 2003 WHO melaporkan, bahwa di negara maju diperkirakan setiap tahunnya ditemukan hanya 10-20 kasus baru diantara 100.000 penduduk.1) Pada tahun 2011 dalam "Global Tuberculosis Report 2012" WHO memperkirakan bahwa ada 8,7 juta kasus baru tuberkulosis, 13\% diantaranya merupakan koinfeksi dengan HIV.2).

Studi tentang hubungan dukungan Pengawas Minum Obat dengan kesembuhan Penderita TB paru di Puskesmas Purwodadi I Kabupaten Grobogan, dengan uji hubungan mempergunakan chi square, diperoleh nilai $p$ lebih besar dari 0,05 , yaitu 0,773 , berarti terbukti secara statistik bahwa tidak ada hubungan antara dukungan PMO dengan kesembuhan Penderita TB paru di Puskesmas Purwodadi I Kabupaten Grobogan 3). Sedangkan Puskesmas Mangkang secara statistik justru menunjukkan ada hubungan yang signifikan Pengawas Minum Obat terhadap kesembuhan pada penderita TBC di wilayah kerja Puskesmas Mangkang Semarang Barat, dengan $p$ value $0,002(\mathrm{p}<0,05), 4)$

Apabila pembuktian determinan tbparu secara analitik menunjukkan hasil yang tidak konsisten, maka akan timbul pertanyaan apakah studi epidemiologi analitik tidak dapat dipergunakan untuk menguji determinan terjadinya kasus tbparu. Bagaimanakah studi epidemiologi analitik sebaiknya dilakukan.

\section{B. Rumusan Masalah}

Tuberkulosis paru adalah penyakit menular yang ganas dan mematikan. Satu dari sepuluh infeksi laten (tersembunyi) akan berkembang menjadi penyakit aktif, yang jika tidak diobati dengan benar akan berakibat fatal bagi penderita. Sebagian besar pasien TB dapat disembuhkan, dengan syarat apabila mereka mematuhi ketentuan yang diberlakukan dalam pengobatan.

Pola hubungan exposure faktor risiko (Dukungan Pengawas Minum Obat) dengan outcome (kesembuhan) dalam pengobatan tb-paru memberikan hasil yang berbeda antara Puskesmas Purwodadi I Kabupaten Grobogan dan Puskesmas Mangkang Semarang Barat. Dengan demikian masalahnya dapat dirumuskan dalam suatu pertanyaan apakah pola hubungan antara faktor risiko dengan outcome terjadi secara kebetulan atau memang berpola tertentu seperti itu? Temuan penelitian yang manakah yang dapat dipergunakan sebagai dasar pemberantasan tb-paru secara nasional? Bagaimanakah menilai pola hubungan tersebut melalui studi epidemiologi yang bersifat analitik?

\section{METODE PENELITIAN}

Studi epidemiologi ini menggunakan metode systematic review. Sumber data penelitian ini berasal dari literatur yang diperoleh melalui internet, penelitian yang relevan, terutama penelitian di Puskesmas Purwodadi I Kabupaten Grobogan dan di Puskesmas Mangkang Semarang Barat.

A. Penelitian di Puskesmas Purwodadi I

Kabupaten Grobogan 3).

a. Jenis penelitian adalah observasional dengan design atau rancangan kasus-kontrol

b. Populasi kasus adalah penderita tuberkulosis paru BTA positif yang dinyatakan tidak sembuh pada periode Januari 2006-Desember 2007 (27 orang). Sedangkan populasi kendali adalah seluruh penderita tuberkulosis paru BTA 
positif yang dinyatakan sembuh pada periode Januari 2006Desember 2007 di Puskesmas Purwodadi I sebanyak 34 orang.

c. Sampel kasus adalah penderita tuberkulosis paru BTA positif yang dinyatakan tidak sembuh yaitu penderita berusia $\geq 18$ tahun, dan sampel kontrol adalah penderita tuberkulosis paru berusia $\geq 18$ tahun, BTA positif yang dinyatakan sembuh.

B. Penelitian di Puskesmas Mangkang

Semarang Barat 4)

a. Jenis penelitian adalah observasional dengan design atau rancangan cross-sectional

b. Populasi dalam penelitian ini adalah penderita TBC yang sudah menjalani pengobatan TB selama 6 bulan yaitu berjumlah 30 orang di wilayah Puskesmas Mangkang.

c. Teknik sampling dalam penelitian ini adalah menggunakan total sampling yakni sebanyak 30 orang

\section{KERANGKA TEORI}

C. Epidemiologi analitik
Penalaran terhadap hubungan faktorfaktor penyebab kejadian ataupun pengaruh tehadap kejadian pada populasi tertentu dapat mempergunakan suatu studi yang bersifat deskriptif maupun studi yang bersifat analitik. Studi yang bersifat deskriptif menekankan analisis ketertarikan pada angka-angka ekstrem tetapi tidak melakukan uji statistik, sehingga tidak dapat dipastikan apakah pola kejadian tersebut terjadi secara kebetulan atau memang berpola tertentu. Sedangkan studi analitik diartikan sebagai rancangan studi untuk menguji hubungan, umumnya yang diduga atau yang dihipotesakan mempunyai hubungan sebab akibat (Analytic study is a study designd to exemine association, commonly putative or hypothesized causal relationships) . 5)

Instrumen untuk menilai hubungan risk factors dengan outcome dalam studi epidemiologi umumnya mempergunakan analisis Odds Ratio. Analisis tersebut menggunakan tabel $2 \times 2$ dengan informasi yang dibutuhkan dalam uji statistik disajikan pada tabel pada gambar 1 berikut ini. 6)

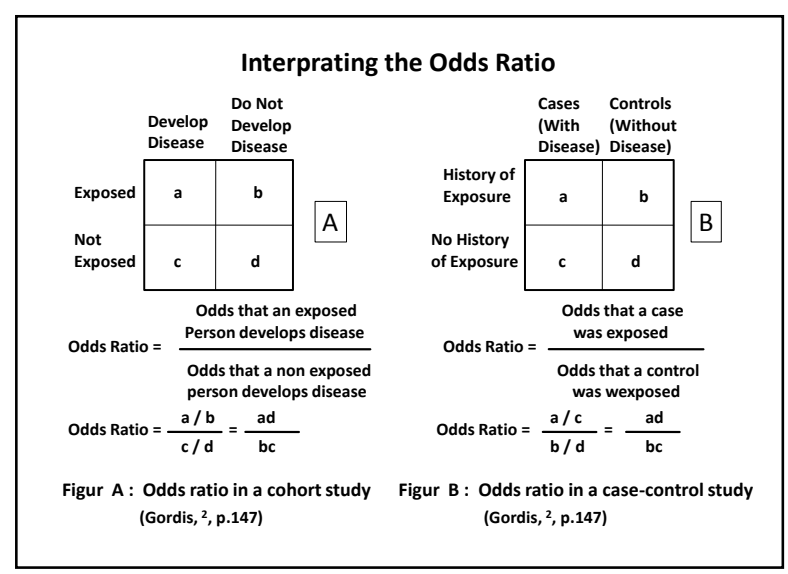

Sesuai dengan konsep pengertian analitik, yaitu tindakan menjabarkan suatu obyek kajian menjadi komponen atau bagian per bagian. Kemudian masingmasing bagian tersebut dipelajari secara khusus. Jika informasi yang diperoleh dari kajian bagian per bagian tersebut disatukan, maka akan diperoleh informasi yang utuh (menyeluruh) dari obyek kajian tersebut. Tindakan menyatukan informasi tentang bagian-bagian menjadi informasi tentang obyek secara utuh dikenal dengan istilah sintesis. Pada gambar 1 yang dimaksud bagian-bagian itu adalah data dan informasi tentang isi sel "a", sel "b", sel "c", sel "d". Dengan demikian suatu studi epidemiologi dikatakan bersifat analitik, jika memuat informasi tentang "a", "b", "c", dan "d". Jika studi epidemiologi hanya mengumpulkan data tentang populasi $(a+b+c+d)$, atau data sub populasi pajanan $(\mathrm{a}+\mathrm{b})$ dan sub populasi bukan pajanan 
$(\mathrm{c}+\mathrm{d})$, atau sub populasi kasus $(\mathrm{a}+\mathrm{c})$ dan sub populasi bukan kasus $(b+d)$ dan tidak memiliki data untuk mengisi ke-4 sel "a", sel "b", sel "c", sel "d", maka studi tersebut tidak termasuk studi yang bersifat analitik. Studi yang demikian adalah studi populasi (karena unit analisisnya populasi) dan studi kasus (case series), karena unit analisisnya yang mendapat outcome (+) saja. Studi yang demikian termasuk bersifat studi deskriptif, meskipun jika mempergunakan instrumen uji statistik.

D. Faktor Kesembuhan Pengobatan tbparu

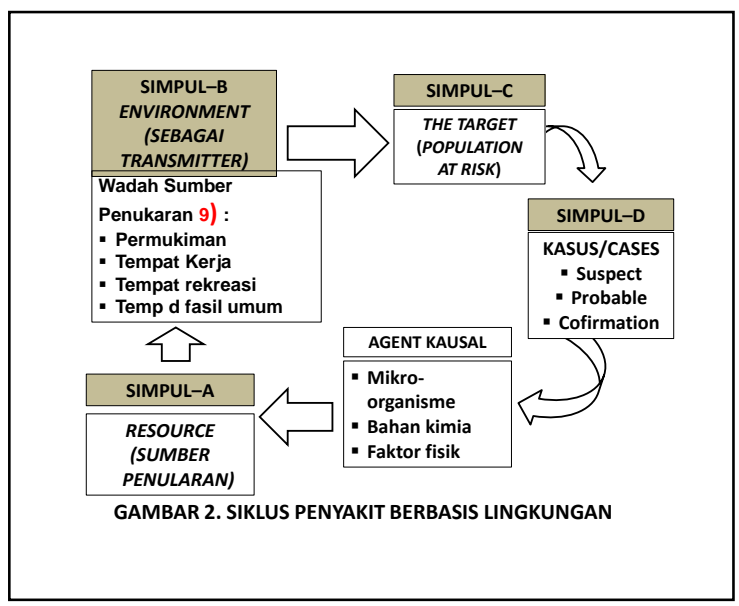

Beberapa faktor yang mempengaruhi tingkat kesembuhan pengobatan tb-paru antara lain adalah :

1) Faktor internal, antara lain : umur, jenis kelamin, tingkat pendidikan, status gizi, kebiasaan merokok, penyakit penyerta, pengetahuan, dan seterusnya.

2) Faktor eksternal, antara lain : lingkungan pekerjaan, status sosial
Penyakit tb-paru merupakan salah satu penyakit berbasis lingkungan, dapat dikelompokkan ke dalam "airborne disease' karena penularan penyakit ini dapat disebarkan melalui unsur lingkungan atmosfer melalui mekanisme ðroplet infection. Simpul pengamatan penyakit dalam kajian Epidemiologi Lingkungan dapat dilihat pada gambar 2, sedangkan kerangka konsep hubungan keteraturan atau kepatuhan minum obat anti tuberkulosa dengan kesembuhan pasien tbparu dapat dilihat pada gambar 3 berikut ini.

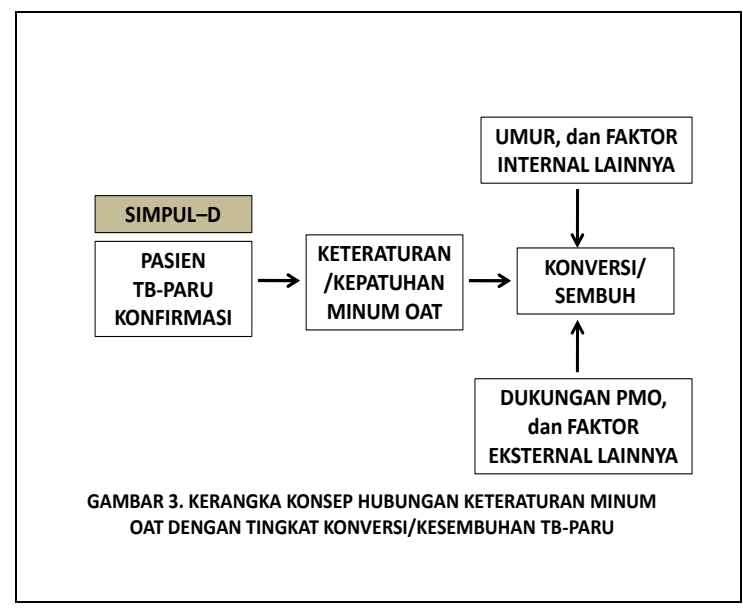

ekonomi, tinggal serumah dengan penderita tb, kondisi rumah, keteraturan minum OAT, PMO, dan seterusnya.

II. HASIL DAN PEMBAHASAN

A. Hubungan dukungan PMO dengan kesembuhan.

A. Puskesmas Purwodadi I Kabupaten Grobogan

Tabel 3. Tabel Silang Faktor Dukungan PMO Dengan

Kesembuhan TB-paru di Puskesmas Purwodadi I Tahun 2010

\begin{tabular}{|l|c|c|c|}
\hline $\begin{array}{c}\text { DUKUNGAN } \\
\text { PMO }\end{array}$ & $\begin{array}{c}\text { TIDAK } \\
\text { SEMBUH }\end{array}$ & SEMBUH & NILAI $\mathrm{p}=$ \\
\hline Tidak ada & 16 & 14 & \multirow{2}{*}{0,773} \\
\hline Ada & 9 & 11 & \\
\hline
\end{tabular}

Hasil uji Chi Square menghasilkan nilai $p$ value $=0,773$, dengan demikian secara statistik terbukti tidak ada hubungan antara dukungan PMO dengan kesembuhan Penderita TB paru di Puskesmas Purwodadi Tahun 2010. Studi epidemiologi di Puskesmas Purwodadi diatas merupakan studi 
yang bersifat analitik. Hal itu mengingat kriteria ketersediaan data sel "a", sel "b", sel "c", dan sel "d" tersedia, yaitu sebesar 16 responden, 14 responden, 9 responden, dan 11 responden. Puskesmas Mangkang Semarang Barat

Tabel 4. Tabel Silang Faktor Dukungan PMO Dengan

Kesembuhan TB-paru di Puskesmas Mangkang Tahun 2012

\begin{tabular}{|l|c|c|c|}
\hline $\begin{array}{c}\text { DUKUNGAN } \\
\text { PMO }\end{array}$ & SEMBUH & TIDAK SEMBUH & NILAI $\mathrm{p}=$ \\
\hline Aktif & 15 & 3 & 0,002 \\
\hline Tidak aktif & 3 & 9 & \\
\hline
\end{tabular}

Hasil uji Chi Square menghasilkan nilai $p$ value $=0,002$, dengan demikian secara statistik terbukti ada hubungan antara dukungan PMO dengan kesembuhan Penderita TB paru di Puskesmas Purwodadi Tahun 2013. Studi epidemiologi di Puskesmas Mangkang diatas juga merupakan studi yang bersifat analitik. Hal itu mengingat kriteria ketersediaan data sel "a", sel "b", sel "c", dan sel "d" tersedia, yaitu sebesar 15 responden, 3 responden, 3 responden, dan 9 responden.

\section{B. Pembahasan}

A. Komparasi Aspek Penelitian

Penelitian hubungan keteraturan minum OAT dengan kesembuhan pasien tbparu yang dilakukan pada tempat, waktu, metode yang berbeda sangat mungkin akan menghasilkan temuan yang berbeda pula. Komparasi dari penelitian hubungan dukungan PMO dengan tingkat kesembuhan tb-paru dari dua studi yang berbeda dapat dilihat dari beberapa aspek. a. Rancangan studi di Puskesmas Purwodadi 1 (kasus kontrol) dengan penelitian di Puskesmas Mangkang (potong lintang).

Analisis hubungan faktor risiko (satu faktor risiko) dengan outcome, atau analisis pengaruh variabel bebas terhadap veriabel terikat paling ideal jika dilakukan dengan rancangan kohort. Sebab kohort merupakan suatu metode studi prospektif yang dimulai dari suatu populasi yang mungkin terpajan atau tidak terpajan faktor risiko, atau terpajan dengan derajat yang berbeda dengan faktor yang dihipotesakan mempengaruhi probabilitas kejadian. Implikasi dari studi ini memerlukan populasi yang besar, atau waktu yang lama, atau keduanya yaitu populasi besar dan lama.10)

Sedangkan rancangan potong lintang seringkali tidak dapat menjelaskan urutan pajanan (atau tingkat pajanan) faktor risiko terhadap outcome. Diskripsi tentang rancangan kohort digambarkan dengan jelas pada gambar 4 berikut.

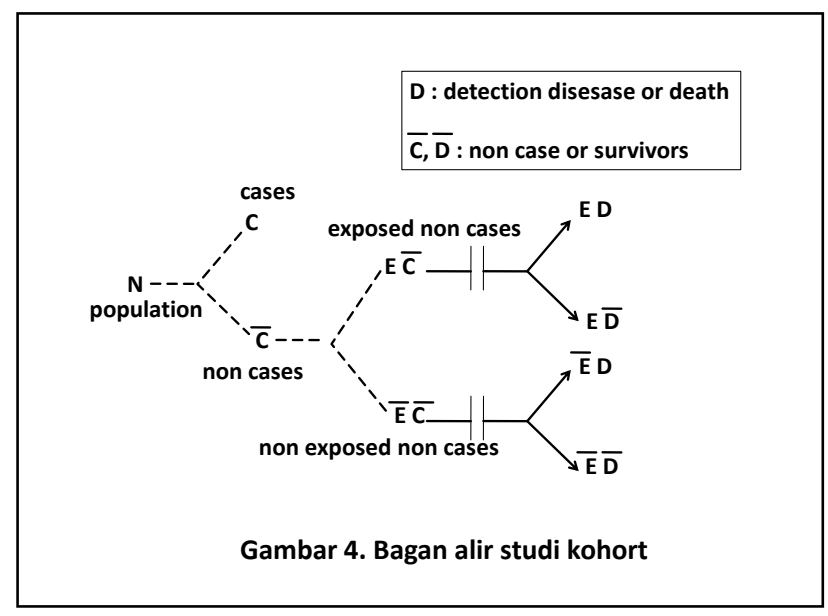


b. Sampel di Puskesmas Purwodadi 1 (responden berusia $\geq 18$ tahun, kasus 25 orang, dan kontrol 25 orang) dengan penelitian di Puskesmas Mangkang (saturated sample 30 orang).

Analisis dukungan PMO terhadap tingkat kesembuhan di Puskesmas Purwodadi dilakukan terhadap sampel yang dicuplik secara purposive atau quota sample, yaitu responden (pasien tb-paru) yang berrumur $\geq 18$ tahun baik sebagai kasus maupun sebagai kontrol. Sedangkan di Puskesmas Mangkang analisis dilakukan terhadap seluruh pasen tb-paru (saturated sample). Seluruh responden adalah pasien tb-paru yang telah menjalani pengobatan selama 6 bulan.

Berdasarkan alasan efisiensi, maka pemilihan sampel kedua jenis penelitian tersebut diatas tidak dicuplik secara probability sampling. Oleh sebab itu hasil temuan kedua penelitian tersebut tidak dapat diberlakukan untuk menilai hubungan dukungan PMO dengan kesembuhan tb-paru di Indonesia umumnya dan wilayah puskesmas lainnya. Temuan tersebut hanya berlaku spesifik di tempat dimana dilakukan penelitian, yaitu pasien tb-paru di puskesmas masingmasing.

Perbedaan temuan penelitian tersebut adalah bahwa penelitian di Puskesmas Purwodadi 1, variabel umur sebagai variabel pengganggu telah dikendalikan pada fase perencanaan (yaitu dengan menentukan batas usia $\geq 18$ tahun sebagai anggota responden. Penelitian di Puskesmas Mangkang pengaruh atau hubungan umur responden (penderita) terhadap tingkat kesembuhan tidak dikendalikan pada tahap rencana, tidak pula dilakukan penilaian tingkat pengaruhnya pada tahap uji statistik, dengan demikian tidak dapat dibuktikan ada tidaknya hubungan antara umur penderita dengan tingkat kesembuhan tb-paru dalam pengobatan. Namun demikian ternyata pada penelitian lain terbukti secara statistik bahwa tidak ada hubungan antara umur penderita dengan ketaatan meminum OAT dan tingkat kesembuhan tb-paru. Penelitian di Kota Manado menunjukkan bahwa umur responden yang dibagi menjadi 3 tingkat (skala ordinal) yaitu dewasa muda (15-24 tahun), menengah (25-49 tahun), dan dewasa tua ( $\geq 50$ tahun), ternyata tidak mempunyai hubungan dengan kepatuhan minum OAT ( $p=0,337)$. 9) Sedangkan kepatuhan minum OAT mempunyai hubungan yang bermakna dengan kesembuhan tb-paru dengan nilai $p=0,005$. Jadi umur responden tidak mempunyai hubungan dengan tingkat kesembuhan tbparu. 3)

\section{B. Metode pembuktian determinan (verifikasi)}

Setiap aktivitas pengukuran akan mempunyai 4 peluang hasil, yaitu : 1 ) benar dikatakan benar; 2) benar dikatakan salah; salah dikatakan salah; dan 4) salah dikatakan benar. Peluang kesalahan selalu ada, karena secara kodrati tidak mungkin manusia benar 100\%. Parameter yang berkaitan dengan kesalahan pengukuran dikenal dengan akurasi dan presisi. Akurasi menunjukkan kedekatan nilai hasil pengukuran dengan nilai sebenarnya, dan Presisi menunjukkan tingkat reliabilitas dari data yang diperoleh. 10)

Selain hal itu metode pembuktian hubungan atau pengaruh faktor " $\mathrm{A}$ " terhadap kejadian " $B$ " menggunakan uji statistik. Apabila ditemukan adanya hasil uji statistik yang tidak sesuai dengan teori yang sudah dipercaya secara umum, maka perlu dilakukan verifikasi dan penelusuran metodelogi penelitian untuk menjawab keraguan tentang fenomena tersebut. Halhal yang perlu diperhatikan dalam uji statistik, antara lain adalah besar sampel dan cara pengambilan sampel.

a. Besar sampel

Representasi sampel untuk sebuah populasi merupakan syarat mutlak apabila hasilnya akan diberlakukan secara general (inferensial). Pada dasarnya semakin homogen nilai variabel yang diteliti, semakin kecil sampel yang dibutuhkan, sebaliknya semakin heterogen nilai variabel yang diteliti, semakin besar sampel yang dibutuhkan. Di samping keterwakilan populasi (kerepresentatifan), hal lain yang perlu dipertimbangkan dalam menentukan besar sampel adalah keperluan analisis. Beberapa analisis atau uji statistik 
memerlukan persyaratan besar sampel minimal tertentu dalam penggunaannya.

Banyaknya atau besarnya sampel yang diambil menjadi menjadi lebih penting jika penelitian menggunakan analisis parametrik (kuantitatif), akan tetapi pada penelitian yang menggunakan analisis nonparametrik (kualitatif), ukuran sampel bukan menjadi nomor satu, karena yang dipentingkan adalah kekayaan informasi. Sampel menjadi lebih bermanfaat jika bersamanya dilakukan pengumpulan data sebanyak-banyaknya variabel atau informasi.

Ketentuan tentang besarnya sampel dalam suatu penelitian inferensial bergantung kepada penelitinya dan tujuan serta rancangan penelitian. Ada yang menyatakan besar sampel cukup 10\% saja, ada pula yang menyatakan cukup $30 \%$ saja. Namun demikian apabila peneliti ingin mengetahui besarnya sampel dengan derajat kepercayaan, presisi, tertentu maka perlu mempergunakan bantuan rumus yang disesuaikan dengan rancangan studinya. Berbeda rancangan studinya (Crosssectional, case control dan Chohort) mempunyai konsekwensi penggunaan rumus yang berbeda pula.11) Penentuan besar sampel yang tidak memperhitungkan nilai alpha $(\alpha)$ dan Z, seperti besar sampel yang ditetapkan dalam kedua penelitian ini nampaknya tidak dapat dinilai sebagai representasi kasus pengobatan tb-paru secara universal, akan tetapi hanya diberlakukan secara spesifik untuk subyek penelitian di Puskesmas Purwodadi 1 dan Puskesmas Mangkang saja.

b. Cara pengambilan sampel

Secara umum cara pengambilan sampel dibagi menjadi dua, yaitu : 1) Probability/Random Sampling, terdiri dari Simple Random Sampling, Stratifieed Random Sampling, Cluster Sampling, Systematic Sampling, dan Area Sampling; dan 2) Nonprobability/Nonrandom Sampling (convenience sampling, purposive sampling atau judgement dan quota sampling, snowball sampling). Apabila seluruh anggota populasi dijadikan sampel, misalnya pada Total Sampling atau Saturated Sampling, maka cara ini termasuk kelompok Non Probability Sampling.
Mengingat studi yang dilakukan di Puskesmas Purwodadi 1 dan Puskesmas Mangkang, dilakukan dengan cara purposive sampling dan cara saturated sampling, maka cara pengambilan sampel kedua studi ini termasuk Non Probability Sampling.

\section{KESIMPULAN DAN SARAN}

a. Kesimpulan.

1. Pola hubungan faktor risiko (=dukungan PMO) dengan outcome (=kesembuhan tb-paru) di Puskesmas Purwodadi I dan Puskesmas Mangkang tidak terjadi secara kebetulan, akan tetapi berpola secara menetap.

2. Temuan studi pada Puskesmas Purwodadi I hanya berlaku dilingkungan Puskesmas Purwodadi I, dan temuan di Puskesmas Mangkang hanya berlaku untuk Puskesmas Mangkang saja.

3. Metodelogi dalam studi tidak mempergunakan kaidah metodelogi inferensial, maka hasilnya tidak dapat diberlakukan secara inferensial untuk kasus tb-paru secara general.

4. Kedua studi tersebut merupakan studi analitik, akan tetapi mempergunakan metode yang berbeda sehingga hasilnyapun berbedda.

b. Saran.

1. Dengan alasan keyakinan bahwa "exposure" harus terjadi sebelum "outcome", maka studi yang mempelajari hubungan faktorfaktor risiko (banyak faktor) dengan outcome sebaiknya mempergunakan rancangan kasuskontrol. Cohor study menjadi lebih baik apabila faktor risiko yang dipelajari tunggal atau satu jenis saja.

2. Agar temuan studi epidemiologi dapat dipergunakan untuk dasar pengambilan keputusan secara lebih luas (generalisasi atau inferensial), maka metode penelitian sebaiknya mempergunakan kaidah-kaidah inferensial. 
Daftar Pustaka :

1) Helda Nurmalasari, Hubungan Pelaksanaan Strategi DOTS Dengan Angka Kesembuhan pada penderita TBparu di Puskesmas Se Kabupaten Tanah Laut Tahun 2010, Skripsi D-4 Epidemiologi Lingkungan, JKL, Poltekkes Banjarmasin, 2012, hal.1

2) Anonim. Available from : http://unud789-830426399-tesis tb, study casecontrol, pdf.author : IBM, Title : Penelitian Epidemiologi Analitik, diakses 29 September 2014, h.

3) Murtantiningsih, Bambang Wahyono, Faktor-Faktor Yang Berhubungan Dengan Kesembuhan Penderita Tuberkulosis Paru, Jurnal Kesehatan Masyarakat, KEMAS 6 (1) (2010) 4450, ISSN 1858-1196, http://journal.unnes.ac.id/index.php/k emas , Email: bambangwahyono@yahoo.com

4) Nuha Muniroh ${ }^{1}$, Siti Aisah $^{2}$, Mifbakhuddin $^{3}$, Faktor-Faktor Yang Berhubungan Dengan Kesembuhan Penyakit Tuberculosis (Tbc) Paru Di Wilayah Kerja Puskesmas Mangkang Semarang Barat, ipi98549, Jurnal Kesehatan Masyarakat, KEMAS 6 (1) (2011) 44-50

5) John M.Last, A Dictionary of Epidemiology, $2^{\text {nd }}$ Ed, Oxford University Press, 1988

6) Leon Gordis, Epidemiology, W.B.Saunders Company, Philadelphia, Pennsylvania, 1996

7) Menteri Hukum Dan Hak Asasi Manusia Republik Indonesia, Peraturan Pemerintah Republik Indonesia Nomor 66 Tahun 2014 Tentang Kesehatan Lingkungan, www.hukumonline.com

8) David G. Kleinbaum, Lawrence L. Kupper, Epidemiologic Research Principles And Quantitative Methods, Hal Morgenstern Van Nostrand Reinhold Company; New York; 1982, Chapter 5, p.62-.

9) Priska P. H Kondoy, ${ }^{*}$ Dina V Rombot, $\dagger$ Henry M.F Palandeng, $\uparrow$ Trevino A Pakasi, Faktor-Faktor Yang Berhubungan Dengan Kepatuhan Berobat Pasien Tuberkulosis Paru di Lima Puskesmas di Kota Manado,
Jurnal Kedokteran Komunitas dan Tropik, Vol.II Nomor 1 Februari 2014, hal.1-8; 4038-8928-1-PB.pdf

10) Suyatno, Menghitung Akurasi dan Presisi; http://suyatno.blog.undip.ac.id/catego ry/mata-kuliah-materi-kuliah/

11) Ir. Suyatno, MKes,Menghitung Besar Sampel Penelitian Kesehatan Masyarakat, www.suyatno.blog.undip.ac.id; hp.08122815730 